\title{
Exploratory Reform of Collective Construction Lands Marketization in Rural Areas
}

\author{
Shuqin Zhao \\ College of Land Resources and Rural-Urban Planning \\ Hebei GEO University \\ Shijiazhuang, China
}

\author{
Hongfei An \\ College of Land Resources and Rural-Urban Planning \\ Hebei GEO University \\ Shijiazhuang, China
}

\begin{abstract}
Nowadays, channels of collective construction land conversion to cities have started gradually, yet due to influences of numbers of holders of collective construction land use, among collective economic organizations there is a lower transaction size, inactive, especially there are no obvious experience and modes to drive the construction of new villages and beautiful villages. To approve collective construction land conversion within a county, set up a county-based rural collective construction land reserve warehouses, carry out listing and purchase and reserve system for rural collective construction land will play an active role in meeting the demand for rural newly increased collective construction land through county land market, expanding the collective construction land conversion range step by step, improving urbanization level and advancing the construction of beautiful villages as well as increasing farmers' income.
\end{abstract}

Keywords-collective construction land; market-oriented land; county-based land market; collective construction land reserve warehouse

\section{INTRODUCTION}

Lands are resources, assets and capitals, such characteristics of land resources make it much more complicated than pure resources, assets or capitals. The reform of land systems in China initially happened in rural areas, currently the difficulty for reforms is still kept in rural areas, and the current focus is the form of collective construction lands. Reforms of collective construction lands in rural areas underwent the following stages: Law of administration on Lands released in 1986 which forbid land conversion, land nationalization through requisition in 2014, construction land increase-decrease balance in 2007, operating construction land conversion approved in 2008, operative collective lands owning the same type, price and right as state-owned lands in 2013, steady progress of housing property right mortgage, guarantee and transfer in rural areas in 2014, Implementation Suggestions Concerning Establishing a Mechanism Connecting Urban Construction Land Increase Size with Number of Transferred Agricultural Population jointly released by five ministries and commissions in 2016. The reforms of market-oriented collective construction lands in rural areas underwent about 20 years, at present it is still in an initial and exploratory stage. The reforms of market-oriented

This article is among research results of Hebei Technological Department Program (Program No.: 16K55407D). collective construction lands in rural areas have face barriers in laws and regulations such as Property Law where collective lands in rural areas are out of the uniform registered system of real estate [1], which causes lower efficiency of collective construction land use in rural areas, blocking the land ownership value from maintaining and increasing, besides, it is restricted by the social development level, for example, there are huge gaps in property, income and social security between urban and rural areas. However, the collective construction land marketization in rural areas is a necessary trend, and an inevitable choice for urban and rural construction land market integration and uniform land policies in urban and rural areas, this article tries its best to offer an efficient way to drive the marketization of collective construction lands.

\section{CharaCteristics OF COLLECTIVE CONSTRUCTION LANDS IN RURAL AREAS}

\section{A. Unbalanced Distribution of Collective Construction Lands}

The data source in "Table I" is from the Current Land Use Structures given in Overall Land Use Layout in 2006-2020 concerning Daxing (Beijing), Dingzhou (Hebei) and Nanhai (Guangdong) among 33 pilot counties (regions) ${ }^{[2]}$. Proportion of farming lands in Dingzhou is 71\%, 31\% higher than $40 \%$ in Nanhai. Proportion of collective construction lands in Dingzhou is $12.37 \%, 22.14 \%$ lower than $34.51 \%$ in Nanhai. Seen from the above, the collective construction lands in China are unbalanced in distribution, which directly causes huge differences in land welfare and income of farmers.

TABLE I. $\quad$ LAND USE STRUCTURE In PILOT COUNTIES UNIT: HA.

\begin{tabular}{|c|c|c|c|}
\hline Type & $\begin{array}{c}\text { Dingzhou } \\
\text { (Hebei) }\end{array}$ & $\begin{array}{c}\text { Daxing } \\
\text { (Beijing) }\end{array}$ & $\begin{array}{c}\text { Nanhai } \\
\text { (Guangdong) }\end{array}$ \\
\cline { 1 - 3 } Total farming lands & 91868.33 & 65775.23 & 43062 \\
\cline { 1 - 2 } Total construction lands & 23974.49 & 33495.58 & 50891 \\
\cline { 1 - 1 } $\begin{array}{c}\text { Where: Land occupation } \\
\text { for rural residents }\end{array}$ & 15986.32 & 11177.54 & 36986 \\
\cline { 1 - 2 } Urban construction lands & 2983.01 & 17457.07 & 6785 \\
\hline Total land area & 129166.5 & 103595.39 & 107155 \\
\hline
\end{tabular}

\section{B. Low Efficiency of Collective Construction Land Use}

Many phenomena such as "one household having several houses, high vacancy rate of farmers' houses and farmers' homestead out of limits" show, the homestead use efficiency in the country is generally lower. Rural areas have no 
infrastructures such as "water, electricity and road supply and smooth ground" owned by cities which also prove that there are no adequate public and infrastructure-targeted lands in rural areas, which are poorer in undeveloped regions. Due to the influences of township enterprises, collective construction lands generally carry periphery or weaker industries, there are few high added value industries besides and the agglomeration degree is lower. In addition, the enterprise transformation and upgrade and financing have faced different dilemma compared to that of state-owned enterprises, most have few benefits. For example, the land lease modes in Kunshan (Jiangsu) and Nanhai (Guangdong) and self-development modes in Huaxi Village and Zhenggezhuang Village (Beijing) have lower occupation of collective construction lands ${ }^{[3]}$. Seen from the above, there are no continuous potentials to support the collective economic development and farmers' income through collective construction lands.

\section{Collective Construction Land Conversion in a Lower Size}

From homestead replacement in Tianjin to two separations and two switches in Jiaxing (Zhejiang), to double collection in Kunshan (Jiangsu) and to shareholding system in Foshan (Guangdong), on the one hand, there are few pilot areas, the collective construction land conversion size occupies a lower proportion in total construction lands; on the other hand, there exist stored collective construction lands scattered, unfair benefits distribution, vague mechanisms as well as corresponding contradictions, all of these have influenced the conversion size. The lack of laws and regulations as well as low benefits for the construction land conversion, as well as too many worries about the conversion risks the people hold also influence the collective construction land conversion size. In addition, the construction of land resources market is always focused on state-own construction lands, as a result, there are no adequate systems for collective construction land conversion and conversion management systems, which also influence the conversion size.

\section{ANALYSIS ON THE ENVIRONMENT OF THE} MARKETIZATION OF RURAL COLLECTIVE CONSTRUCTION LAND

\section{A. Interest-related Parties of the Collective Construction Land}

The market for the collective construction land in our country is divided into the market for residential land, the market for commercial construction land and the market for the public and infrastructure land. The subject is the market for residential land and the market for commercial construction land. The market for residential land involves residential land, the right of use and the holder of the right of use for the residential land and the market and the administrator of the residential land. The residential land comprises the newly increased and the stock. At present, in order to obtain the right of use of the newly increased residential land, the villagers of the collective apply, and the village collective submits the application to the town government, and the land department of the county-level government approves. That's to say, the newly increased residential land must meet two conditions:
First, it is the family of villagers of the collective. Second, the farmland, unused land and other collective construction land in the collective can be transferred and changed. Therefore, the holder of the right of use of the newly increased residential land is the members of the collective according to the current laws. At present, the holder of the right of use of the residential land in stock is the villagers of the collective, the original members of the collective that settle down in cities and the few settlers from other places. Obviously, the condition of the villager family of the collective limits the quantity of the newly increased residential land. The scope of the holder of the right of use of the residential land in stock limits the number and scope of transaction of the residential land.

The market for the collective commercial construction land involves the collective commercial construction land, the right of use of the construction land and the holder of the right of use, the market and the administrator. The right of use of the collective commercial construction land will be established after the new enterprises bring in business or establish the application for joint venture and the county-level people's government approves. The holder of the right of use can be villagers of the village, the economic organizations of the collective, and the enterprises jointly established by villagers and collective organizations and other units and individuals through the land use rights. There are three types of enterprise of the collective commercial construction land: the enterprise established by villagers, the enterprises established by collective organizations and the enterprises established by both of them. The scale of market transaction will be inevitably restricted because of the few type of business entity and the inadequate power of market transaction. In addition, with the connection of the city and rural construction land and the implementation of the policy for the overall development of the city and rural construction land, the quantity of the collective commercial construction land in stock will reduce. Besides, the increasing difficulty of the newly increased collective commercial construction land has an adverse impact on the transaction scale of the collective commercial construction land.

\section{B. The Policy Environment of the Collective Construction Land}

Our country has introduced policies of constructing the new socialist countryside, the construction of the beautiful villages and the development of urban and rural integration, in order to seek the new development road for rural areas. [4] It is a long-term social existence in rural China. Therefore, except for the regurgitation-feeding compensation, strengthening the hematopoietic function of the rural collective and the subjectivity of the self-construction is to fundamentally and constantly construct the new villages and beautiful countryside. In reality, both the urban and rural overall development and the city and countryside integration contain the improvement of the urbanization level and the construction of the beautiful countryside. The government at the meantime promotes the construction of the beautiful countryside through the marketization of the rural collective construction land.

According to the supply and demand of the collective construction land, because of the small amount of the legal 
subjects that supply land and the small amount of the right of use of the collective construction land and the inactive transaction, the effects of promoting the urbanization of population and improving the land utilization efficiency through the circulation of the collective construction land are indistinctive. Particularly, no significant experience and models exist in promoting the construction of new villages and beautiful countryside. Although the government promotes actively, compared with the market for the urban construction land, the government has a week effect in the market for the collective construction, especially failing to enormously promote the construction of the new countryside. Therefore, increasing the transaction subjects of the rural collective construction land and efficiently using the rural collective construction land can change the single channel that the rural collective construction land flows into cities and strengthen the strength of the rural collective organizations.

\section{Promote the Marketization Frame of the RURAL COLlECTIVE CONSTRUCTION LAND STEP BY STEP}

\section{A. Marketization Frame}

The marketization of the collective construction land is an irresistible trend, and the key is to promote through the effective paths. The marketization frame is divided into the initial stage and the developmental stage.

The initial stage includes two contents: First, the circulation of the collective construction land within the county is allowed. The concrete measures are as follows: establish the reserve of the rural collective construction land in county area, and implement the policy of listing and expropriation and storage of the rural collective construction land. After the peasant households give up the right of use of the residential land, the villagers or the collective organizations in the villages give up the right of use of the collective commercial construction land and the collective economic organizations give up the right of use of the collective public infrastructure land, they can list it in the visible land market in the county or can be expropriated and stored by the government. The collective construction land after the expropriation and storage can integrate with the overall planning of the city and rural construction land through the comprehensive improvement or integrate with the construction of the beautiful countryside. The traders are the peasant household in the county, the collective enterprises, or the joint ventures via collective investment or the land reserve organization in the county. Second, the needs of the newly increased collective construction land in rural areas can be met through the land market in the county. That's to say, the needs of the newly increased residential land in the county are met through the circulation of residential land in the county; the needs of the newly increased commercial construction land are met through the circulation of the collective commercial construction land in the county and the transfer of the residential land in stock in the county; the urban and rural overall development is implemented on the collective public construction land in the county.

In the developmental stage, realize the circulation of the collective construction land in the administrati ve region of the city and finally realize the circulation in the province or wider scope. The rural land reform from land contract to "the separation of three rights" has been used for more than ten years in solving the problem of food and clothing of farmers and striving for a relatively comfortable life. The urban land system reform from the compensated use of the land use rights to the "bid inviting, auction and listing" of the land use rights has been used for nearly twenty years in promoting the urbanization. The construction of the new villages and the beautiful countryside is a long process. The phased implementation and steady promotion of the circulation of the collective construction land will bring real benefits for the rural collective economic organizations and the family of villagers.

\section{B. The Characteristics of New Frame}

The new frame has three functions. First, improve the urbanization level; second, promote the construction of the beautiful countryside; third, increase the income of farmers. According to "Fig. 1", villagers obtain the money paid for the residential land purchased in the transaction. The potential population with the quantity of $\mathrm{p}_{2}$ and the potential holding of funds with the quantity of $r_{2}$ flow into towns. According to "Fig. 2", because the villagers of other villages settle in the constructed village through the circulation of residential land and contracted land, the potential population with the quantity of $p_{3}$ and the potential holding of funds with the quantity of $r_{3}$ in the constructed village flow into towns. The new system can make the potential population with the quantity of $\left(\mathrm{p}_{2}+\mathrm{p}_{3}\right)$ and the funds with the quantity of $\left(r_{2}+r_{3}\right)$ flow into towns, promoting the improvement of the urbanization level.

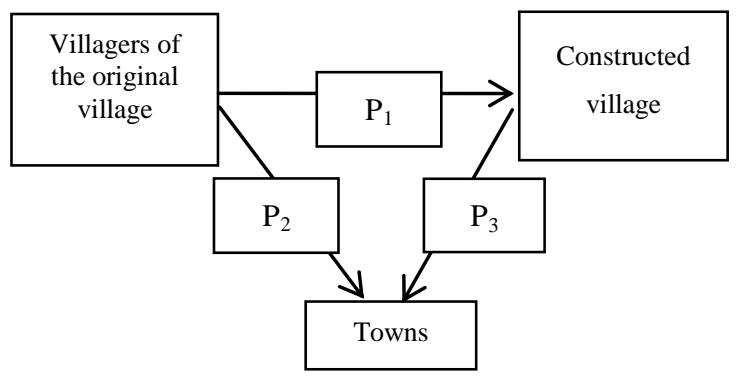

Fig. 1. The transfer of population and money between villages (a).

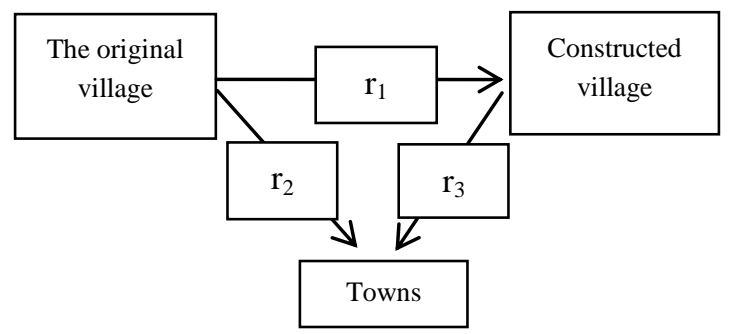

Fig. 2. The transfer of population and money between villages (b).

The circulation of the population of $\left(\mathrm{p}_{1}-\mathrm{p}_{3}\right)$ and the funds of $\left(r_{1}-r_{3}\right)$ in the constructed village indirectly achieves the goal of the comprehensive improvement of the land such as "the relocation and combination of villages" and "the centralized residence of villagers", effectively promoting the intensive use 
of lands in the village and expanding the circulation scale of the collective construction land and farming land in the village at the same time increasing the quantity of the ecological land in the area and improving the ecological environment.

Villages is divided into four types according to the space region, namely the village in the city, the village with the integration of town and country, the village near the city and the village far from the city. Generally speaking, the input of the infrastructure and public facilities and the economic and social conditions in the village decrease successively from the near to the distant. The non-agricultural employment opportunities of villagers decrease successively from the near to the distant, and the land income and wealth accumulation of villagers reduce successively from the near to the distant. The circulation provides the opportunities for villagers to increase the differential income and wealth of the land through the circulation of the collective construction land. Besides, for the constructed village, because of the immigration of people, the transfer prices of properties like the land improve, the level of the material input of land and the concentration degree of cultivated land improves, and at the meantime, the overall land operation income and the property of peasant households increase.

\section{CONCLUSION}

With the implementation of the confirmation of collective land right, the current channels for the transfer of the collective construction land to the city has gradually opened. However, influenced by the quantity of the holder of the right of use of the collective construction land, the transaction scale between the collective economic organizations is small and the transaction is inactive. Particularly, no significant experience and models form in promoting the construction of new villages and beautiful countryside. Establish the reserve for the rural collective construction land in the county and implement the systems of listing and expropriation and storage of the rural collective construction land in stock; the needs of the newly increased rural collective construction land are met through the land market in the county. The phased expansion of the circulation scope of the collective construction land has a positive significance on improving the urbanization level, promoting the construction of beautiful countryside and increasing the income of farmers.

The urban and rural overall development and the city and countryside integration include the improvement of the urbanization level and the construction of the beautiful countryside. The government shall promote the construction of the beautiful countryside through the marketization of the rural collective construction land. The construction of the beautiful countryside can be promoted through expanding the circulation scope of the collective construction land step by step and the marketization of the rural collective construction land. The economic and social problems such as the environmental pollution, soil pollution and water pollution even poverty relief in rural areas can be solved through overall planning and seizing the opportunity of circulation. Improving the land market system in rural areas and the circulation scale has a positive significance on activating the land capital in rural areas, developing and expanding the strength of rural areas.

\section{REFERENCES}

[1] Gao Xin, Zhang Dongping. Research on the Problems of the Marketization of Rural Collective Construction Land [J], Regional Economic Review, 2016, (3):113-119.

[2] The Web Portal of the Ministry of Land and Resources [EB/OL]. http://www.mlr.gov.cn/zwgk/ghjh/201105/t20110520_867995.htm, 2017-3-25/2017-4-6

[3] Wang Min, Zhu Peixin, Zhang Zhilin. Study on Collective Construction Land Transfer Revenue Sharing Mechanism: Take Kunshan City for Example [J], China Land Sciences, 2016,30 (2):51-57.

[4] Dong Yue, Hua Chen. Types Of Villages And Their Development Strategies Based On The Balance Of Economic, Construction, And Ecology [J], Planners, 2017,1 (33):128-133. 